servation scheme which has included the trapping and moving to conservation areas of $\mathbf{2 , 4 0 0}$ beavers. It has proved remarkably successful; no more movement of brceding stock is necessary and there is every indication that the beaver population will increase sharply in the years to come. The engineering ingenuity of the beaver is once again taking its part in the building and safeguarding of the forests of the province. 'Through the construction of dams the beaver establishes and maintains water levels, which in turn create pools essential to the other wild life. Furthermore, the broadened streams and dammed watcrs have proved invaluable in the control of fire, that great foe which jeopardizes both the wild life itself and also the livelihood of the trappers.

\title{
WILD LIFE PROTECTION IN JAMAICA
}

\section{By F. W. Мarch, Conservator of Forests}

In Jamaica the responsibility of administering the Wild Iife Protection Law rests with the Forest Department. 'The Department is assisted and directed by the Wild Life Protection Committee, a body nominated by His Excellency the Governor and consisting of legislators, scientists, sportsmen and Government officials. The policy of this Committee and the Forest Department is to ensure the protection of all forms of wild life consistent with the interests of legitimate sportsmen and with the control of pests.

Jamaica can rightly claim that its wild life includes unique examples of birds and animals. During comparatively recent years several species of birds and the once common iguana have become extinct; in every case the mongoose is largely to blame. The mongoose has now adjusted itself into the balance of nature but only at the expense of the climination of practically all ground nesting birds. The avoidance of another such debacle, whether by human or natural agency, is one of the most important duties of the Wild Life Protection Committee.

The aspect of wild life conservation most in the public eye is the vexed question of game-lirds, what to shoot, when to shoot, and where to shoot.

Most species of pigeons and doves are classed as "game" and may be shot during the "open season". Important exceptions are the Ruddy Quail Dove or Partridge, the Mountain Witch, and the Blue Pigeon; unfortumately specimens of these 
birds are all too frequently included in the "sportsman's." bag. It is an acknowledged fact that the pigeon population is decreasing year by year. Many reasons are advanced to account for this ; over-shooting in and out of season, destruction of feeding areas due to agricultural development, and, of course, the shooting of migratory birds in other territories. The first case can be cured by legislation but only with the co-operation of all sportsmen and public opinion ; the second cause can only be remedied in some small way by gun cluls and private landowners.

Another factor leading to the depletion of bird life is the small, sometimes not so small, boy with his sling-shot or catapult. The importation of catapult clastic has been prohibited for many years but unfortunately strips of old imner tubes serve the same purpose. The handling of this menace is entirely in the hands of parents and teachers. Some years ago the writer was accompanying a member of the House of Representatives in a country district when the latter was presented with a eomplaint that worms (caterpillars) were destroying crops and suggesting that Government might help; this happened to be in an area where every small boy was armed with a catapult.

An important aspect of wild life protection is that of preservation of the fish life in our streams and rivers. Here the Forest Department, assisted by the newly-formed Fisheries Division, is pursuing the good work initiated by the Ingling Association of Jamaica. I few years ago most of our inland waters were in danger of losing all their fishy inhabitants, thanks to uncontrolled netting, dynamiting and poisoning. Now there is in existence a service of River Wardens assisted hy various Forest Department Rangers and Headmen. As a result of this protection and propaganda work, the stock of fish in most of our rivers is once more on the increase.

'The Wild Life Protection Committee has interested itself in the problems of the booby egg collections on the Morant and Pedro Cays; the maintenance of the turtle population around our coasts ; pollution of rivers, and a myriad of other problems of lesser import, but all tending towards the one object of preserving Jamaica's wild life heritage. 